\title{
Executive Strength, Executive-Legislative Relations, and Budget Deficits
}

\author{
Hojun Lee and Jae Hyeok Shin
}

\begin{abstract}
Why do different countries experience varying levels of budget deficits? Common pool resource theorists argue that budget deficits tend to be low if the executive, who considers total tax burdens, suppresses the narrow incentives of individual legislators, who only consider partial tax burdens. Policy inertia theorists argue that a decrease in the number of veto players is associated with a low level of budget deficit. In this article, we combine the two approaches and offer a conditional common pool resource theory that predicts budget deficits to decrease as the executive strength vis-à-vis the legislature increases under parliamentarism because of the lack of legislative veto power. Under presidentialism, however, this effect is not likely to be significant because of the presence of legislative veto power. We support the argument through an analysis of cross-national data on budget deficits of 49 countries from 1995 to 2011.
\end{abstract}

Key Words: budget deficits, executive strength, executive-legislative relations, parliamentary system, presidential system, conditional common pool resource theory

$\mathrm{T}$ his article aims to investigate why different countries experience varying levels of budget deficits. Budget deficits can have significant economic consequences (e.g., national savings, future national income) as well as political consequences (e.g., reelection prospect) and the level of budget deficits is an important indicator of the government's macroeconomic performance. ${ }^{1}$ Early economists have suggested the "tax-smoothing hypothesis" and argued that the government is the "benevolent social planner" that always balances the budget and thus budget deficits only occur under extraordinary circumstances such

*Hojun Lee (hjlee87@korea.ac.kr) is a PhD Candidate at Korea University, Seoul, ROK.

Jae Hyeok Shin (shinj@korea.ac.kr) is an Assistant Professor of Political Science and International Relations at Korea University. His articles have appeared in Political Science Quarterly, Democratization, and Japanese Journal of Political Science.

Previous versions of this article have been presented at the World Congress for Korean Politics and Society, August 23, 2013 and at the quarterly meeting of the Korean Association of International Studies, April 26, 2014. The authors thank Sang Hun Lim, Tae Eun Min, Sung Woo Lee, Seunghee Yoo, Hyun Jin Cha, Jung Woo Lee, and the three anonymous reviewers for their valuable comments. All remaining errors are our own responsibility. This research was supported by the National Research Foundation of Korea under the Global PhD Fellowship Program funded by the Ministry of Education of the South Korean Government (grant number: NRF-2013H1A2A1032524).

The Korean J ournal of International Studies Vol.12 No. 2 (December 2014), 451-472.

http://dx.doi.org/10.14731/kjis.2014.12.12.2.451

(c) 2014 The Korean Association of International Studies 
as wars or recessions (Barro 1979; Lucas and Stokey 1983). However, the taxsmoothing hypothesis does not fit the reality where some countries suffer from large deficits while others do not (Roubini and Sachs 1989a). Thus, scholars have turned their attention to the different levels of budget deficits across countries.

Two approaches have evolved to explain the effects of political factors on budget deficits. Common pool resource (CPR) theorists assume a "common pool resource problem" (Ostrom 1990) in budget decision making and argue that fiscal balance is undermined by the narrow interests of individual politicians who tend to exploit the budget in order to deliver targeted benefits to constituents (Roubini and Sachs 1989a/1989b). ${ }^{2}$ The solution presented by this theory is to delegate more authority to the national political leader who tends to care about the total tax burden. Thus, the CPR theorists argue that when the executive suppresses the incentives of individual legislators, budget deficit will be lowered (Von Hagen and Harden 1995 ; Harden and von Hagen 1999; Kontopoulos and Perotti 1999; Harden and Marier 2004). On the other hand, policy inertia (PI) theorists argue that the level of budget deficits is associated with the number of veto players (Tsebelis 2002). As the number of veto players increases, it becomes more difficult to change the current policy. Thus, an increase in the number of veto players in the system is likely to undermine the government's ability to adjust budget deficits, which is likely to result in larger deficits (Roubini and Sachs 1989a/1989b; Alt and Lowry 1994; Franzese 2002; Tsebelis 2002; Tsebelis and Chang 2004). ${ }^{3}$

In this article, we offer a new theory-conditional common pool resource theory-combining those two approaches to explain the level of budget deficit in a country. We argue that the executive control over the legislature decreases budget deficits on the condition that the legislature does not have an institutional veto power. That is, the effects of executive strength on budget deficits should be significant in a parliamentary system because the legislators, who do not consider total tax burdens, are more disciplined by the executive and thus lack veto power. However, we expect that executive strength will not have a significant effect on budget deficits in a presidential system because the legislators are less disciplined and thus have the institutional veto power against the executive.

We test our arguments using the World Bank's data of budget deficits in 49

\footnotetext{
${ }^{1}$ For discussions on the economic consequences of budget deficits see for example Gale and Orszag (2003). For political consequences of budget deficits, see Brender and Drazen (2008).

2 Roubini and Sachs (1989a/1989b) argue that multiparty governments tend to have higher deficits because coalition partners want to deliver benefits to their constituents at the expense of the total tax burden.

${ }^{3}$ Although Roubini and Sachs (1989a/1989b) do not mention the term "veto players" in their articles, a part of their argument is similar to that of the veto players theory because they emphasize that multiparty governments tend to be slower in adjusting to fiscal shocks because the budget process is highly inefficient when there are many stakeholders in the government.
} 
countries from 1995 to 2011. We find that an increase in the share of ruling party's seats in the legislature is negatively correlated with budget deficits only in parliamentary system. Conversely, an increase in the share of ruling party's seats is not correlated significantly with budget deficits in presidential systems.

This article offers at least two contributions to the literature on budget deficit. First, the article attempts to combine the two strands of the literature that examine the effects of political institutions on budget deficits-the common pool resource theory and the policy inertia theory-and suggests a conditional common pool resource theory. Second, unlike many preexisting studies that focus only on the executive strength or on the differences between parliamentarism and presidentialism (Roubini and Sachs 1989a/1989b; Alt and Lowry 1994; Harden and von Hagen 1999; Kontopoulos and Perotti 1999; Tsebelis 2002; Hankla 2013), this article shows that an interaction of executive strength and parliamentarism/presidentialism can lead to a different budget outcome.

The remainder of this article is as follows. In section two we briefly review the preexisting literature on budget deficit. In section three we explain the logic of our argument and generate testable hypotheses. In section four we describe the data and specify the statistical model to test the hypotheses. We present the results of our empirical analysis and discuss the findings in section five, and conclude in section six.

\section{COMMON POOL RESOURCE PROBLEM OR POLICY INERTIA?}

Budget deficits arise from governments' excessive expenditure. Early economists that examined the causes of budget deficits offer the tax-smoothing hypothesis which views the government as the "benevolent social planner" that always tries to balance the budget and predicts that deficits only arise under exceptional circumstances such as wars or recessions (Barro 1979; Lucas and Stokey 1983). However, recent studies have shown that budget deficits do happen in the absence of wars or recession and there are cross-national differences in budget deficits. Thus, many scholars have turned their attention to the effects of political factors on budget deficits. In this section, we briefly review two strands of the literature-common pool resource theory and policy inertia theory-that examine the impacts of political factors on budget deficits.

The common pool resource theorists assume that there is a "common pool resource problem," in which individual rationality undermines collective rationality when distributing common pool resources (Ostrom 1990). They view the budget as a common pool resource and argue that the common pool resource problem-in which politicians exploit the budget for their individual interests 
without considering the total tax burden-cause high budget deficit. Roubini and Sachs (1989a/1989b), for instance, argue that budget deficits are caused by multiparty governments in parliamentary systems because the coalition partners in the government tend to exploit the budget in order to deliver benefits to their constituents at the expense of a balanced budget. Thus, most of the CPR literature argues that when a central actor, who considers the total tax burden, has the power to suppress the individual politicians' incentives to exploit the budget, deficit will decrease. Many studies have found empirical support for the CPR theory of budget deficits. For instance, Von Hagen and Harden (1995) analyze the patterns of budget deficits in 12 EU member states from 1981 till 1990 and find that countries that delegate budgetary power to a strong central player show lower budget deficits because a strong central player that considers the total tax burden can solve the CPR problem. Similarly, Harden and von Hagen (1999) and Harden et al. (2007) examine budget deficits in 20 democracies from 1981 to 1994 and find that a centralization of power leads to a favorable condition for a lower budget deficit. Specifically, they explain that majoritarian electoral systems are more likely to produce balanced budgets because the executives are more likely to be empowered by single-party governments, in which a strong financial minister can control the budget process. However, they also explain that multiparty governments can produce balanced budgets if the financial minister is empowered to enforce the fiscal contract formed by the coalition partners. In addition, in their study of budget outcomes in Latin American countries, Harden and Marier (2004) also emphasize that a weak executive increases budget deficits. They find that the executive's strong control over the legislature effectively reduces budget deficits.

The policy inertia theorists, on the other hand, emphasize the importance of the number of veto players who can block a change of status quo. Franzese (2002) argues that the presence of many veto players decreases the government's ability to adjust the budget during fiscal shocks. Additionally, Tsebelis (2002) shows with spatial models that the presence of multiple veto players creates a "policy inertia" effect, which makes it harder for the government to reduce budget deficits. Many studies have found empirical support for the PI approach to budget deficits. For instance, Roubini and Sachs (1989a/1989b) find in their analysis of budget deficits in 15 Organization for Economic Cooperation and Development (OECD) countries that budget deficits tend to be higher with multiparty governments. Alt and Lowry (1994) examine the patterns of budget deficits of state governments within the United States and found that divided state governments, where the executive and the legislative branches are held by different parties, tend to be less efficient in responding to fiscal shocks and thus produce higher levels of budget deficits than unified state governments. Tsebelis and Chang (2004) also find in their analysis of 19 industrialized countries from 
1973 to 1995 that countries with multiple veto players have difficulty in altering budget structures, which, in turn, undermines the government's ability to reduce budget deficits.

The two theoretical approaches differ in their causal mechanism but they share the same idea that predicts a centralization of political power to reduce budget deficits. Hence, some scholars have attempted to provide a more integrated approach of the two theories. For instance, Hankla (2013) criticizes that most studies only examine the patterns of budget deficits in parliamentary systems and argues that the dynamics of budgetary politics in presidential systems should be differentiated from that of parliamentary systems. Hankla (2013) finds that in presidential systems, unified governments do indeed produce low deficits but even divided governments tend to produce low deficits when fragmentation is high in the legislature. This is because the president's political survival is not threatened by a fragmented legislature and thus, the president can co-opt small opposition parties when the legislature is fragmented whereas this would not be possible if a single opposition party controls the legislative majority (Hankla 2013). Hankla's study emphasizes the importance of a central actor, or the president, that would solve the CPR problem but also highlights the impact of different executive-legislative relations in presidential and parliamentary systems on budget outcomes. However, Hankla's (2013) theory only focuses on the impact of executive strength and legislative fragmentation on budget deficits in presidential systems.

\section{HYPOTHESIS}

In this section, we will derive testable hypotheses from the two contending theories of budget deficits-common pool resource theory and policy inertia theory-in order to test the individual effects of each theory. We will then combine the two approaches to offer a conditional common pool resource theory which predicts that executive strength reduces budget deficits on the condition that the legislature does not have an institutional veto power.

As stated in the CPR literature on budget deficit, an increase in the executive strength vis-à-vis the legislature decreases budget deficits because the executive, who represents the national constituency and considers the total tax burden, tend to prefer a balanced budget whereas the legislators tend to exploit the budget in order to deliver particularistic benefits to their constituencies. Thus, we expect that:

Common Pool Resource Hypothesis (H1): As the executive strength vis-à-vis the legislature increases, budget deficits will decrease. 
On the other hand, the policy inertia theorists argue that budget deficits arise in systems with multiple veto players. In order to change policies, certain veto players must agree to the proposed change and the presence of multiple veto players may stagnate the budgetary policymaking process, which, in turn, would undermine the government's ability to reduce budget deficits (Tsebelis 2002; Tsebelis and Chang 2004). As for budgetary policymaking, how veto power is distributed among the executive and the legislature can have significant effects on budget outcomes because they can be institutional veto players or actors specified by the country's constitution that has to agree to a proposed change (Tsebelis 2002, 2) in the budgetary process (Wildavsky 1992). Thus, we can expect budget deficits to be lower in a parliamentary system where there is only one institutional veto player (the executive) because the executive controls the legislative majority. Conversely, budget deficits should be higher in a presidential system compared to a parliamentary system because the executive does not have control over the legislature and thus, there are two institutional veto players (the executive and the legislature). Specifically we expect that,

\section{Policy Inertia Hypothesis (H2): Parliamentarism produces lower budget} deficits than presidentialism.

Next, we offer a conditional common pool resource theory which combines the two approaches. We predict that there should be an interaction effect of executive strength and parliamentarism/presidentialism on budget deficits. Precisely, the effects of executive strength on budget deficits should be conditional on the presence of legislative veto power because even though the legislators may want to exploit the budget in order to deliver benefits to their constituents at the expense of a balanced budget (Mayhew 1974), they cannot pursue their individual goals if they are not empowered to do so.

Under parliamentarism, the executive and the legislature are mutually dependent on each other for survival. As a result, legislators under parliamentarism tend to be disciplined by the parties and especially those legislators affiliated with the ruling parties tend to be more disciplined. That is because the prime minister, who is also the leader of the ruling parties, imposes strong discipline on his party members in order to reduce the risk of a defeat in legislative votes, which, in turn, would lead to a dissolution of the cabinet (Linz 1994; Mainwaring and Shugart 1997; Samuels and Shugart 2010). Moreover, the executive's power to dissolve the legislature is another effective tool to suppress the narrow incentives of individual legislators.Under parliamentarism, the prime minister usually has the power to dissolve the parliament and to call for new elections. This would facilitate executive discipline on the legislature because the legislators should be less likely to challenge the prime minister at the risk of losing their seats in the new elections. It may be possible that the parliament's 
vote of no confidence may discipline the executive but the prime minister, who is the leader of the ruling party, would be able to punish his party members for any attempts to dismiss the cabinet. ${ }^{4}$ Therefore under parliamentarism, the legislature does not have an institutional veto power, and an increase in the executive strength vis-à-vis the legislature (e.g., an increase in seat share of ruling party in the legislature) would thus decrease budget deficits.

Under presidentialism, however, the legislature is an institutional veto player because it is independent of the executive to survive (Haggard and McCubbins 2001; Samuels and Shugart 2010). Legislators are thus less disciplined in presidentialism than their counterparts in parliamentarism. Hence the former tend to be more empowered to pursue individual goals. It may be argued that in the unified presidential government where president's party controls the majority seats in the legislature, the legislature may not be considered as a veto player because of the partisan cohesion of the two branches. Nevertheless, the legislators still tend to be less disciplined in presidentialism because they have weaker incentives to comply with the president's interests at the expense of their own interests due to the independence from the executive for survival (Linz 1994; Mainwaring and Shugart 1997). Thus, it can be expected that under presidentialism, legislators tend to exploit national resources at the expense of a balanced budget in order to deliver benefits to their constituents, irrespective of executive strength over the legislature. Hence we expect that:

Conditional Common Pool Resource Hypothesis (H3): As the executive strength vis-à-vis the legislature increases, budget deficits will decrease only under parliamentarism.

\footnotetext{
${ }^{4}$ Empirically, few prime ministers are defeated by a vote of confidence in parliamentary systems regardless of unified or coalition governments. For example, the parliament's vote of no confidence defeated one prime minister in the United Kingdom since 1924, none in Australia, one in Germany since 1982, one in Greece, etc.
} 
Figure 1. Conditional Common Pool Resource Theory

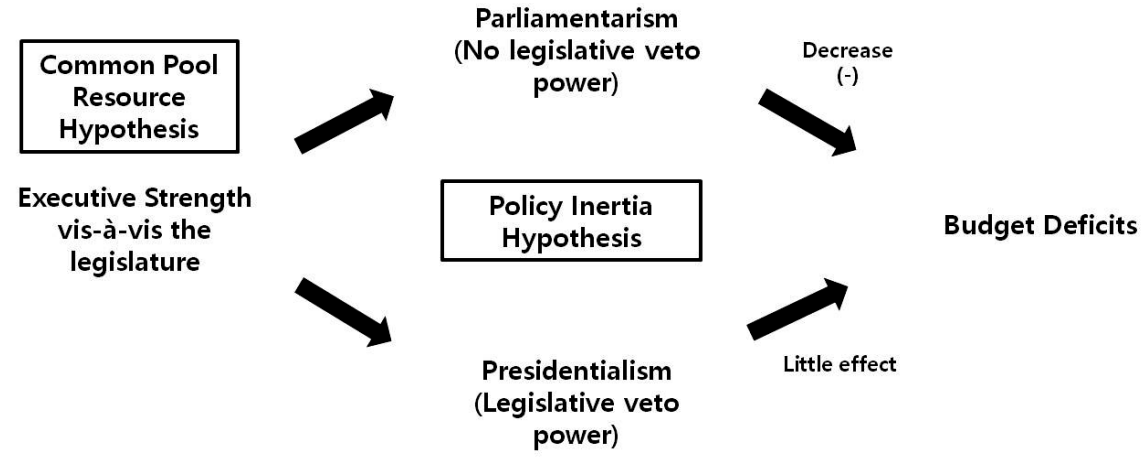

\section{DATA, MODEL, AND MEASURES}

We test the above hypotheses using cross-national data of 49 countries. The dataset includes Argentina (2002-2004), Armenia (2003-2011), Australia (1999-2011), Austria (1995-2011), Bangladesh (2001-2006, 2009-2011), Belgium (1995-2011), Bolivia (2002-2007), Brazil (1997-2011), Bulgaria (1995-2011), Canada (1995-2011), Chile (2000-2011), Colombia (2001-2011), Denmark (1995-2011), Dominican Republic (2004-2010), Finland (1995-2011), France (1995-2011), Germany (1995-2011), Greece (1995-2011), Guatemala (1995-2011), Honduras (2003-2011), Hungary (1995-2011), Indonesia (19951999, 2002-2011), Italy (1995-2011), Japan (2005-2011), South Korea (19952011), Malaysia (1996-2011), Mexico (1995-2000), the Netherlands (19952011), New Zealand (2001-2011), Nicaragua (1995-2011), Norway (2000-2011), Paraguay (1995-2011), Peru (1995-2011), the Philippines (2000, 2003-2011), Poland (2001-2011), Portugal (1995-2011), Russia (2006-2011), Singapore (1995-2011), Spain (1995-2011), Sri Lanka (1995-2011), Sweden (1995-2011), Switzerland (1995-2011), Thailand (2003-2011), Turkey (2006-2011), United Kingdom (1995-2011), United States (1995-2011), Ukraine (2006-2011), Uruguay (1995-2011), and Venezuela (1995-2005).

The dependent variable is Deficit ${ }_{i t}$, indicating country $i$ 's budget deficit in year $t$. We use the World Bank Databank's Annual Budget Surplus/Deficit data, in which a country's government budget surplus or deficit is calculated in percentage of gross domestic product (GDP). Because the focus of this study is the level of budget deficits, we inverse the World Bank data in order to assign positive values to deficits and negative values to surpluses. Deficit $_{i t}$ ranges from -20.4 to 16.9 with a mean of 1.2. 
Because we use time-series-cross-sectional data and a continuous dependent variable, we construct a fixed-effects regression model to measure the interaction effect of executive strength and executive-legislative relations on budget deficits while controlling for unobservable time-invariant factors in regional contexts (e.g., similar historical experience, culture, etc.). The basic model for country i's budget deficit in year $t$ is

$$
\begin{aligned}
& \text { Deficit }_{i t}=\beta_{0}+\beta_{1} * \text { Executive Strength }_{i t}+\beta_{2} * \text { Parliamentarism/ } \\
& \text { Presidentialism }_{i t}+\beta_{3}{ }^{*} \text { Executive Strength }_{i t} * \text { Parliamentarism/ }^{*} \\
& \text { Presidentialism } \\
& \text { Prt } \beta_{4} * \text { Controls }_{i}+\mathrm{R}_{\mathrm{i}}+\varepsilon_{i, t}
\end{aligned}
$$

where $\mathrm{R}$ represents the region-specific dummy variables and $\varepsilon$ represents the random error term. A country's executive strength is affected by how strong the control of the executive over the legislature is and executive-legislative relations are affected mainly by whether a country adopts parliamentarism or presidentialism. We operationalize executive strength, parliamentarism/ presidentialism, and some key control variables as follows.

\section{PARLIAMENTARIANISM/PRESIDENTIALISM}

Using the World Bank's Database of Political Institutions (DPI 2012), we generate a dummy variable, Parliamentarism , $_{i}$, to indicate whether a country is a parliamentary system or a presidential system. In DPI 2012, countries in which the chief executive is elected and can be easily recalled by the legislature are classified as parliamentarism. We categorize all the other cases, including semipresidentialism in which the president is elected directly by voters and cannot be easily removed by the legislature, as presidentialism. Parliamentarism ${ }_{i t}$ is coded 1 if country $i$ is parliamentarism in year $t$; 0 otherwise. That is, the variable is coded $o$ if country $i$ is presidentialism in year $t$. Of 652 cases in the dataset $57.8 \%$ are parliamentary systems and the rest are presidential systems.

\section{EXECUTIVE STRENGTH}

Executive Strength refers to the percentage of seats that ruling parties take in the legislature. Most preexisting studies use a dummy variable whether or not the ruling parties are in a majority in the legislature to measure the executive strength over the legislature (Lijphart 1984). Instead of the dummy variable, we use the proportion of parliamentary seats, because the latter contains more precise information about the executive strength vis-à-vis the legislature. For example, if ruling parties are in a supermajority in the legislature, they would have less difficulty controlling the legislature than when they are in a bare majority; if they take $25 \%$ of the parliamentary seats, they would have more difficulty than when they take $49 \%$ of the seats (Shin 2013). This variable ranges from 20.6 to 100 , with a mean of 57.2. 
Whether a country adopts parliamentarism or presidentialism is expected to interact with the executive strength in affecting the country's budget deficit. Because the expectation is that as the executive strength over the legislature increases, budget deficits will decrease in parliamentary systems, we expect Parliamentarism $_{i t}{ }^{*}$ Executive Strength $_{i t}$ to correlate negatively with Deficit $_{i t}$.

\section{CONTROL VARIABLES}

In addition to those key variables of interest, several other factors may affect a country's budget deficit. First, fragmentation in the legislature and in the cabinet should be controlled for. Fragmented legislatures, in which a large number of parties take parliamentary seats, and fragmented cabinets, in which a large number of parties take cabinet posts, tend to decrease the stability of the cabinets (Laver and Schofield 1990; Warwick 1994), and may thus undermine the executive's ability to reduce budget deficit (Tsebelis 2002; Hankla 2013; Roubini and Sachs 1989a, 1989b; Harden and von Hagen 1999). Legislative fragmentation is the effective number of legislative parties collected by Bormann and Golder (2013); Cabinet fragmentation is obtained from DPI 2012, which is coded $\mathrm{o}$ if the country has a single-party government, 1 if a two-party government, 2 if a three-party government, and 3 if four-or-more-party government.

Second, a country's economic condition could affect the country's budget deficit (Barro 1979; Lucas and Stokey 1983). The proponents of the tax-smoothing hypothesis argue that macroeconomic conditions may have an effect on budget deficits. We include GDP per Capita (log) to control for the effects of a country's economic conditions. Data for GDP per capita is obtained from the World Bank Databank.

Third, political leaders in democracies may be more likely to increase budget deficits than their counterparts in autocracies, because the former tend to have a larger winning coalition (should receive support from a larger number of people) and would thus need to distribute benefits to a broader population (Bueno de Mesquita et al. 2003). We thus use a dummy, Democracy, for 597 cases (out of 652) where countries are classified as a democracy by Cheibub et al. (2010). ${ }^{5}$

Finally, because we use time-series cross-national data, we control for time- and region-fixed effects. Dummy variables for observation years are included in the models in order to control for unknown time-invariant year-specific factors that may affect Deficit. Next, to control for unknown time-invariant region-specific factors, dummy variables for world regions are generated because countries in the same world region tend to share similar attributes such as political institutions and to experience the same exogenous shock such as the 1997 Asian

\footnotetext{
${ }^{5}$ A country is democratic if (1) its effective executive is directly elected or selected by an elected assembly, (2) a legislature with multiple parties is elected, and (3) opposition parties or challengers to incumbents are allowed and have realistic chances of taking power (Cheibub et al. 2010).
} 
financial crisis that may affect the level of budget deficits. Forty-nine countries in the dataset are thus grouped into 11 world regions (see Appendix). Additionally, we also control for year dummies in order to control for unobservable timespecific effects. Specifically, we include year dummies for 1997, 2008, and 2009 because of the significant economic crises that happened during those years and economic crises may cause countries to run higher deficits. We run models with the dummies for world regions (without the dummies for countries) because only a few observations are available for some countries. ${ }^{6}$

\section{EMPIRICAL ANALYSIS}

\section{RESULTS}

Table 1 shows the results of our analysis. Executive Strength may be highly correlated with Legislative fragmentation and Cabinet fragmentation because ruling parties tend to take fewer seats in fragmented legislatures, which is likely to lead to a multi-party government to control the majority seats in the legislature (see Shin 2013). Parliamentarism may also be highly correlated with Legislative fragmentation and Cabinet fragmentation for the following two reasons. First, most of the observations (300 out of 377) among parliamentary systems have highly proportional electoral systems, which may be highly correlated with Legislative fragmentation (Lijphart 1990). ${ }^{7}$ Secondly, coalition governments are more common under Parliamentarism especially when the legislature is highly fragmented. Thus, in order to check for multicollinearity, we run models without Legislative fragmentation and Cabinet fragmentation first.

Table 1. Conditional Common Pool Resource Theory and Budget Deficits

\begin{tabular}{|c|c|c|c|c|}
\hline & Model 1 & Model 2 & Model 3 & Model 4 \\
\hline Executive Strength & 0.006 & & $0.044^{* *}$ & $0.034^{* *}$ \\
& $(0.013)$ & & $(0.011)$ & $(0.010)$ \\
Parliamentarism & & 0.116 & $4.507^{* *}$ & $3.652^{* *}$ \\
Parliamentarism * Executive & & $(0.364)$ & $(1.707)$ & $(1.753)$ \\
Strength & & $-0.076^{* *}$ & $-0.079^{* *}$ \\
Legislative fragmentation & & & $(0.027)$ & $(0.026)$ \\
Cabinet fragmentation & & & & 0.067 \\
GDP per capita (log) & $-0.732^{* *}$ & $-0.750^{* *}$ & $-0.836^{* *}$ & $-1.032^{* *}$ \\
& $(0.139)$ & $(0.164)$ & $(0.164)$ & $(0.295)$
\end{tabular}

\footnotetext{
${ }^{6}$ For example, there are only three observations (2002-2004) for Argentina.

${ }^{7}$ This is also the reason why we do not separately control for electoral systems in our models.
} 


\begin{tabular}{|c|c|c|c|c|} 
& $4.085^{* *}$ & $3.954^{* *}$ & $3.472^{* *}$ & $1.781^{* *}$ \\
Democracy & $(0.775)$ & $(0.791)$ & $(0.749)$ & $(0.752)$ \\
Asian Financial Crisis (1997) & -0.268 & -0.274 & -0.330 & -0.640 \\
& $(0.721)$ & $(0.722)$ & $(0.688)$ & $(0.672)$ \\
Global Financial Crisis (2008) & -0.664 & -0.650 & -0.558 & -0.397 \\
& $(0.690)$ & $(0.693)$ & $(0.698)$ & $(0.605)$ \\
Eurozone Crisis (2009) & $2.879^{* *}$ & $2.887^{* *}$ & $2.952^{* *}$ & $3.109^{* *}$ \\
\hline Constant & $(0.673)$ & $(0.675)$ & $(0.655)$ & $(0.551)$ \\
\hline No. of Observations & $3.732^{* *}$ & $4.293^{* *}$ & $3.135^{* *}$ & $6.749^{* *}$ \\
No. of Regions & $(1.317)$ & $(1.430)$ & $(1.490)$ & $(2.975)$ \\
\hline No. of Years & 651 & 651 & 651 & 651 \\
Within $\mathrm{R}^{2}$ & 11 & 11 & 11 & 11 \\
\hline
\end{tabular}

Note: $\dagger=$ significant at the $90 \%$ level, ${ }^{* *}=$ significant at the $95 \%$ level. Robust standard errors are in parentheses. Region dummies are included in Model 4 but coefficients are not reported.

In Column 1 of Table 1, we present the results with Executive Strength. Executive Strength is correlated positively with Deficit but is not statistically significant. This finding contradicts the predictions of the common pool resource theory (Hypothesis 1), which would expect executive strength to have a significant impact in decreasing budget deficits. In Column 2 of Table 1, we include Parliamentarism instead of Executive Strength. Parliamentarism also does not have a significant impact on budget deficits. Thus, Column 1 and 2 of Table 1 demonstrates that the results of our analysis contradict the predictions of the common pool resource hypothesis and policy inertia hypothesis.

Column 3 of Table 1 incorporates both Parliamentarism and Executive Strength, and includes an interaction term of these variables in order to test the conditional common pool resource theory. As expected, as ruling parties take more legislative seats, budget deficits decrease in parliamentary systems; the coefficient on Parliamentarism * Executive Strength is thus negative and significant. Specifically, a unit increase in Executive Strength decreases the level of budget deficits by about $0.08 \%$ points under parliamentarism. Additionally, the $\mathrm{R}^{2}$ of Column 3 is about $10 \%$ higher than the $\mathrm{R}^{2}$ of Columns 1 and 2 , which indicates that our model of conditional common pool resource theory explains the variations of budget deficits better than the models that test the individual effects of the CPR and PI theory. In Column 4 of Table 1, the set of control variables we specified are included in the model. Including the control variables for legislative and cabinet fragmentation in the model does not alter the results substantially. Thus, we can safely discard the multicollinearity concern. The findings of Column 3 and 4 of Table 1 conforms to the conditional common 
pool resource hypothesis, which predicts that an increase in Executive Strength decreases budget deficits only under Parliamentarism. ${ }^{8}$

Some hypothetical examples can help to explain the relevant coefficients by comparing different executive-legislative relations-for example, presidential systems where presidents have strong control over the legislature compared to those where presidents do not control the legislative majority, and parliamentary systems where prime ministers' parties control a majority of parliamentary seats compared to those where ruling parties are in a minority in the parliament. For example, the level of budget deficit in the presidential system where the president's party takes $75 \%$ of legislative seats is $1.7 \%$ higher than that in the presidential system where the ruling party takes $25 \%$ of the seats (2.55\% versus $0.85 \%)$. In contrast, the level of deficit in the parliamentary system where the prime minister's party takes $75 \%$ of parliamentary seats is $2.25 \%$ lower than that in the parliamentary system where the ruling party takes $25 \%$ of the seats (0.28\% versus $2.53 \%$ ).

Figure 2 visualizes how an interaction between parliamentarism/ presidentialism and executive's legislative seats influences the level of budget deficits.

Figure 2. Predicted Budget Deficits (\% of GDP)

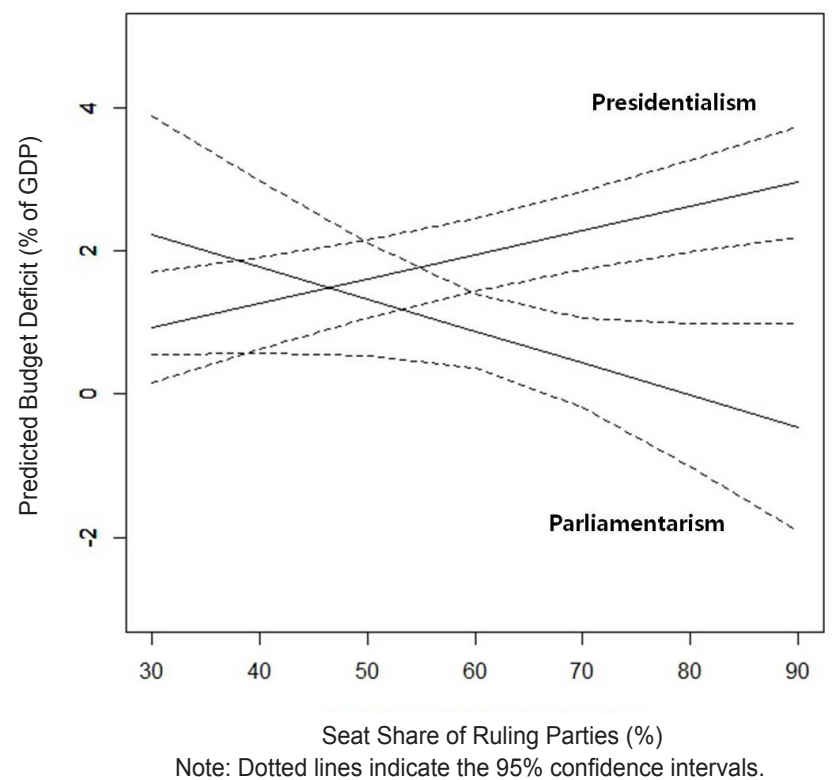

${ }^{8}$ Since Parliamentarism is coded 1 for parliamentary systems and o for presidential systems, it can be predicted that the interaction effect of Executive Strength and Presidentialism is positively correlated with budget deficits. 
As the executive controls more seats in the legislature, budget deficits decrease substantially in parliamentary systems while they do not alter significantly in presidential systems. Hence, the gap between presidentialism and parliamentarism widens as the legislative seats controlled by the executive increase. Comparing a few cases in the dataset can help interpret the results. In a presidential system where the ruling parties control over $75 \%$ of the parliamentary seats, such as the Philippines in 2006, budget deficits amount to 1.25\%. Conversely, deficits amount to $-1.91 \%$ or a surplus of $1.91 \%$ in a parliamentary system where the ruling parties control over $75 \%$ of the parliamentary seats, such as Thailand in 2006. The significant difference in the level of budget deficits (1.25\% versus $-1.91 \%)$ indicate that executive strength vis-à-vis the legislature has a significant impact in reducing budget deficits in parliamentary systems whereas such impact is not so significant in presidential systems. We can also compare these results with a set of cases in which the ruling parties control fewer seats. For example, budget deficits in the Philippines actually decreases by $0.05 \%$ (from $1.25 \%$ to $1.20 \%$ ) in 2008 compared to 2006 despite the dramatic decrease in the ruling parties' seat share (from $76.5 \%$ to $54.18 \%$ ). Conversely, budget deficits in Thailand increases by $1.41 \%$ (from $-1.91 \%$ to $-0.5 \%$ ) despite the slight decrease in the ruling parties' seat share (from $75.4 \%$ to $65.83 \%$ ). The substantive figures demonstrate that the impact of executive strength on budget deficits is significant under parliamentarism while it is not so significant under presidentialism. Thus, our analysis demonstrates that the variations of budget deficits across countries can be explained better with conditional common pool resource theory, rather than with the CPR or PI theory separately.

\section{ROBUSTNESS ANALYSIS}

Although the results of our analysis shown above conform to our predictions of the conditional common pool resource theory, we may suspect that the following issues embedded in analyzing time-series cross-section data may have biased the results of the analysis. First, although we have explained our justification of including region-specific dummies instead of country-specific dummies in our model, there still may be time-invariant factors within each country, rather than the region, which may have an impact on budget deficits. For instance, in some countries unobservable institutional practices may have a significant effect on budget outcomes even under similar institutions. This indicates that our observations may be heteroskedastic and thus our results may be biased. Secondly, budget deficits in year $t$ may be affected by budget deficits in year $t-1$, which indicates that there may be autoregressive disturbances that would bias the results of our analysis.

Thus, we check for the robustness of our results from the potential problems mentioned above by the following treatments. First, we rerun our model using 
the country-fixed effects model. The country-specific fixed effects controls for any country-specific time invariant factors that may have affect budget deficits. ${ }^{9}$ Second, we include a one-year lagged value of the dependent variable and rerun the model to control for autoregressive disturbances. Lastly, we rerun the models with cluster-robust standard errors (CRSE) at the region level. The clusterrobust standard errors controls for any additional region-specific time invariant factors, such as culture and similar historical experience, which may affect budget deficits. Moreover, the cluster-robust standard errors are not only robust to cluster-heteroskedasticity but also to within-cluster correlation (Cameron and Miller forthcoming). However, since the cluster-robust standard errors is more accurate when the number of clusters is large, we also run the model with clusterrobust standard errors at the country level. The results of our robustness analysis are shown in Table 2.

Table 2. Conditional Common Pool Resource Theory and Budget Deficits (Robustness Analysis)

\begin{tabular}{|c|c|c|c|c|}
\hline & $\begin{array}{l}\text { Model } 5 \\
\text { FE }\end{array}$ & $\begin{array}{c}\text { Model } 6 \\
\text { FE with LDV }\end{array}$ & $\begin{array}{c}\text { Model } 7 \\
\text { FE with LDV } \\
\text { \& CRSE } \\
\text { (Region) }\end{array}$ & $\begin{array}{c}\text { Model } 8 \\
\text { FE with LDV } \\
\text { \& CRSE } \\
\text { (Country) }\end{array}$ \\
\hline Executive Strength & $\begin{array}{c}0.017 \\
(0.013)\end{array}$ & $\begin{array}{c}0.006 \\
(0.011)\end{array}$ & $\begin{array}{c}0.006 \\
(0.006)\end{array}$ & $\begin{array}{c}0.006 \\
(0.011)\end{array}$ \\
\hline Parliamentarism & $\begin{array}{l}4.151^{* *} \\
(1.519)\end{array}$ & $\begin{array}{l}3.023^{* *} \\
(1.093)\end{array}$ & $\begin{array}{l}3.023^{* *} \\
(0.927)\end{array}$ & $\begin{array}{l}3.023^{* *} \\
(1.093)\end{array}$ \\
\hline $\begin{array}{c}\text { Parliamentarism * Executive } \\
\text { Strength }\end{array}$ & $\begin{array}{c}-0.083^{* *} \\
(0.026)\end{array}$ & $\begin{array}{l}-0.040^{* *} \\
(0.017)\end{array}$ & $\begin{array}{l}-0.040^{* *} \\
(0.014)\end{array}$ & $\begin{array}{l}-0.040 * * \\
(0.017)\end{array}$ \\
\hline Legislative fragmentation & $\begin{array}{l}-0.130 \\
(0.166)\end{array}$ & $\begin{array}{l}-0.034 \\
(0.093)\end{array}$ & $\begin{array}{l}-0.034 \\
(0.093)\end{array}$ & $\begin{array}{l}-0.034 \\
(0.093)\end{array}$ \\
\hline Cabinet fragmentation & $\begin{array}{c}0.115 \\
(0.155)\end{array}$ & $\begin{array}{c}0.130 \\
(0.112)\end{array}$ & $\begin{array}{c}0.130 \\
(0.114)\end{array}$ & $\begin{array}{c}0.130 \\
(0.112)\end{array}$ \\
\hline GDP per capita (log) & $\begin{array}{c}-0.908^{* *} \\
(0.447)\end{array}$ & $\begin{array}{c}-0.878^{* *} \\
(0.274)\end{array}$ & $\begin{array}{l}-0.878+ \\
(0.396)\end{array}$ & $\begin{array}{l}-0.878^{* *} \\
(0.274)\end{array}$ \\
\hline Democracy & $\begin{array}{c}0.566 \\
(0.455)\end{array}$ & $\begin{array}{c}-0.244 \\
(0.250)\end{array}$ & $\begin{array}{c}-0.244 \\
(0.152)\end{array}$ & $\begin{array}{c}-0.244 \\
(0.250)\end{array}$ \\
\hline Asian Financial Crisis (1997) & $\begin{array}{c}-0.950 \dagger \\
(0.486)\end{array}$ & $\begin{array}{c}-1.138^{* *} \\
(0.497)\end{array}$ & $\begin{array}{c}-1.138+ \\
(0.604)\end{array}$ & $\begin{array}{c}-1.138^{* *} \\
(0.497)\end{array}$ \\
\hline
\end{tabular}

\footnotetext{
${ }^{9}$ Although the random-effects model may be an alternative to fixed-effects model because one of our explanatory variables, Parliamentarism, is time-invariant and may perfectly correlate with country-specific effects. However, we choose to use the fixed-effects model for the following reasons. First, the random-effects model relies on an unrealistic assumption that unobserved country-specific effects are not correlated with the independent variables and thus, the random-effect model is both statistically and theoretically unreliable. Second, the variable of our main interest is the interaction term Executive Strength * Parliamentarism, which is time-variant, and thus the concern for perfect collinearity of the explanatory variable with the country-specific effects can be disregarded.
} 


\begin{tabular}{|c|c|c|c|c|} 
Global Financial Crisis (2008) & $\begin{array}{l}-0.401 \\
(0.265)\end{array}$ & $\begin{array}{l}0.746^{* *} \\
(0.286)\end{array}$ & $\begin{array}{l}0.746^{* *} \\
(0.232)\end{array}$ & $\begin{array}{l}0.746^{* *} \\
(0.286)\end{array}$ \\
Eurozone Crisis (2009) & $\begin{array}{l}3.159^{* *} \\
(0.353)\end{array}$ & $\begin{array}{l}3.859^{* *} \\
(0.405)\end{array}$ & $\begin{array}{l}3.859^{* *} \\
(0.511)\end{array}$ & $\begin{array}{l}3.859^{* *} \\
(0.405)\end{array}$ \\
\hline Constant & $\begin{array}{l}8.790^{\dagger} \\
(4.516)\end{array}$ & $\begin{array}{l}7.869^{* *} \\
(2.673)\end{array}$ & $\begin{array}{l}7.860^{\dagger} \\
(3.900)\end{array}$ & $\begin{array}{c}7.869^{* *} \\
(2.673)\end{array}$ \\
\hline No. of Observations & 651 & 598 & 598 & 598 \\
No. of Regions & 11 & 11 & 11 & 11 \\
No. of Countries & 49 & 49 & 49 & 16 \\
No. of Years & 17 & 16 & 16 & 0.464 \\
Within $\mathrm{R}^{2}$ & 0.123 & 0.464 & 0.464 & 49 \\
\hline
\end{tabular}

Note: ${ }^{\dagger}=$ significant at the $90 \%$ level, ${ }^{*}=$ significant at the $95 \%$ level. In Models 5 and 6 , robust standard errors are shown in parentheses and in Models 7 and 8, cluster-robust standard errors are shown in parentheses. In Models 6-8, 1-year lagged ( $\mathrm{t}-1$ ) value of the dependent variable is included but its coefficients are not reported. FE denotes fixed effects; LDV denotes lagged dependent variable; CRSE denotes cluster-robust standard errors.

As shown in Columns 1-4 in Table 2, the results of the robustness rtests are not substantively different from our analysis shown in Table 1. Column 1 shows the results of the country-fixed effects and the coefficient of the interaction term, Executive Strength * Parliamentarism, is actually higher than the estimates in Table 1. In Columns 2 to 4, the inclusion of a lagged dependent variable suppresses the size of the effect of the interaction term. However, the statistical significance of the interaction term is still well over 95\%. Lastly, in Columns 3 and 4 , inclusion of cluster-robust standard errors at the region and at the country level does not change the results substantially. Therefore, we can infer that the potential bias caused by heteroskedasticity and autoregression in our analysis is negligible.

\section{CONCLUSION}

In this article, we investigate why countries experience different levels of budget deficits. We argue that the executive control over the legislature decreases budget deficits on the condition that the legislature does not have institutional veto power. Using the cross-national data on budget deficits in 49 countries from 1995 to 2011, we find that an increase in seat share of ruling party in the legislature decreases budget deficits in parliamentary systems; it has little impact in presidential systems. 
We make at least two contributions to the literature on budget deficit with this article. First, we attempt to integrate the logics of the two contending theories$\mathrm{CPR}$ versus $\mathrm{PI}-$ on budget deficits in which the CPR theory predicts that a strong executive will decrease deficits and the PI theory predicts that the decrease in the number of veto players will decrease deficits. In this article, we offer a conditional common pool resource theory that contributes to adjudicating this debate by attempting to link the logics of the two theories of budget deficits.

Secondly, this article demonstrates an interaction effect of executive strength and parliamentarism/presidentialism on budget deficits. While most of the pre-existing literature that study the impacts of political factors on budget deficits focused on either the effects of unified versus divided government or the number of parties in the cabinet/legislature (Roubini and Sachs 1989a, 1989b; Alt and Lowry 1994; Harden and von Hagen 1999; Tsebelis 2002), this article focuses on the effects of the different dynamics of executive-legislative relations in parliamentarism/presidentialism on budget outcomes. Considering that most countries in the world have adopted either one of the two constitutional structures-parliamentarism or presidentialism - the findings of this article may have some practical implications for budgetary politics. For instance, parliamentary systems that suffer from high deficits, such as Greece, may be able to reduce deficits by increasing the seat share of the ruling parties in the parliament through elections or through forming grand coalitions whereas such efforts may not be so effective in reducing budget deficits in presidential systems. 


\section{REFERENCES}

Alt, James E. and Robert C. Lowry. 1994. "Divided Government, Fiscal Institutions, and Budget Deficits: Evidence from the States." American Political Science Review 88(4), 811-828.

Barro, Robert J. 1979. "On the Determination of the Public Debt." Journal of Political Economy 87, 940-947

Bormann, Nils-Christian and Matt Golder. 2013. "Democratic Electoral Systems around the World, 1946-2011." Electoral Studies 32, 360-369.

Brender, Adi and Allen Drazen. 2008. "How Do Budget Deficits and Economic Growth Affect. Reelection Prospects? Evidence from a Large Panel of Countries." American Economic Review 98(5), 2203-2220.

Bueno de Mesquita, Bruce, Alastair Smith, Randolph M. Siverson and James D. Morrow. 2003. The Logic of Political Survival. Cambridge, MA: MIT Press.

Cameron, A. Colin and Douglas L. Miller. Forthcoming. "A Practitioner's Guide to Cluster-Robust Inference.” Journal of Human Resources.

Carey, John M. and Matthew S. Shugart. 1995. "Incentives to Cultivate a Personal Vote: A Rank Ordering of Electoral Formulas.” Electoral Studies 14(4), 417-439.

Cheibub, José Antonio, Jennifer Gandhi and James Raymond Vreeland. 2010. "Democracy and Dictatorship Revisited." Public Choice 143 (1-2), 67101.

Franzese, Robert J. 2002. Macroeconomic Policies of Developed Democracies. Cambridge: Cambridge University Press.

Gale, William G. and Peter R. Orszag. 2003. "Economic Effects of Sustained Budget Deficits.” National Tax Journal 56, 463-485.

Haggard, Stephan and Mathew D. McCubbins. 2001. "Introduction: Political Institutions and the Determinants of Public Policy." In Stephan Haggard and Mathew D. McCubbins eds., Presidents, Parliaments, and Policy. New York: Cambridge University Press.

Harden, Mark and Jurgen von Hagen. 1999. "Electoral Institutions, Cabinet Negotiations, and Budget Deficits in the European Union.” In James M. Poterba ed., Fiscal Institutions and Fiscal Performance. Chicago: University of Chicago Press.

Harden, Mark and Patrik Marier. 2004. "Executive Authority, the Personal Vote, and Budget Discipline in Latin American and Caribbean Countries." American Journal of Political Science 48(3), 571-587.

Harden, Mark, Rolf Strauch and Jurgeñ von Hagen. 2007. "The Design of Fiscal Rules and Forms of Governance in European Union Countries." European Journal of Political Economy 23, 338-359. 
Hankla, Charles R. 2013. "Fragmented Legislatures and the Budget: Analyzing Presidential Democracies." Economics \& Politics 25(2), 200-228.

Hicken, Allen and Joel W. Simmons. 2008. "The Personal Vote and the Efficacy of Education Spending." American Journal of Political Science 52(1), 109-124.

Kontopoulos, Yianos and Roberto Perotti. 1999. "Government Fragmentation and Fiscal Policy Outcomes: Evidence from OECD Countries.” In James M. Poterba ed., Fiscal Institutions and Fiscal Performance. Chicago: University of Chicago Press.

Laakso, Markku and Rein Taagepera. 1979. "Effective' Number of Parties: A Measure with Application to West Europe." Comparative Political Studies 12(1), 3-27.

Laver, Michael and Norman Schofield. 1990. Multiparty Government: The Politics of Coalition in Europe. Oxford: Oxford University Press.

Lijphart, Arend. 1984. "Measures of Cabinet Durability: A Conceptual and Empirical Evaluation." Comparative Political Studies 17(2), 265-279. . 1990. Electoral Systems and Party Systems: A Study of Twenty-Seven Democracies, 1945-1990. New York: Oxford University Press.

Linz, Juan J. 1994. "Presidential or Parliamentary Democracy: Does It Make a Difference?" In Juan J. Linz and Arturo Valenzuela eds., The Failure of Presidential Democracy: The Case of Latin America. Baltimore, MD: Johns Hopkins University Press.

Lucas, Robert and Nancy Stokey. 1983. "Optimal Fiscal and Monetary Policy in an Economy without Capital." Journal of Monetary Economics 12, 5594 .

Mainwaring, Scott and Matthew Soberg Shugart. 1997. "Conclusion: Presidentialism and the Party System." In Scott Mainwaring and Matthew Soberg Shugart eds., Presidentialism and Democracy in Latin America. Cambridge, UK: Cambridge University Press.

Mayhew, David. 1974. Congress: The Electoral Connection. New Haven, CN: Yale University Press.

Ostrom, Elinor. 1990. Governing the Commons: The Evolution of Institutions for Collective Action. New York: Cambridge University Press.

Roubini, Nouriel and Jeffrey D. Sachs. 1989a. "Political and Economic Determinants of Budget Deficits in the Industrial Democracies." European Economic Review 33, 908-938. . 1989b. "Government Spending and Budget Deficits in the Industrial Countries." Economic Policy 4(8), 99-132.

Samuels, David J. and Matthew S. Shugart. 2010. Presidents, Parties, Prime Ministers. Cambridge: Cambridge University Press.

Shin, Jae Hyeok. 2013. "Cabinet Duration in Presidential Democracies." Political 
Science Quarterly 128 (2), 317-339.

Tsebelis, George. 2002. Veto Players: How Political Institutions Work. Princeton, NJ: Princeton University Press.

Tsebelis, George and Eric C. C. Chang. 2004. "Veto Players and the Structure of Budgets in Advanced Industrialized Countries." European Journal of Political Research 43, 449-476.

Von Hagen, Jürgen and Ian Harden. 1995. "Budget Processes and Commitment to Fiscal Discipline.” European Economic Review 39(3), 771-779.

Warwick, Paul V. 1994. Government Survival in Parliamentary Democracies. New York: Cambridge University Press.

Wildavsky, Aaron. 1992. The New Politics of Budgetary Process. New York: Harper Collins. 


\section{APPENDIX. COUNTRIES AND REGIONS}

\begin{tabular}{|c|c|c|c|c|}
\hline World Region & $\mathbf{N}$ & Country & $\mathbf{N}$ & $\begin{array}{l}\text { Ave. Budget Deficit }{ }^{\mathrm{a}} \\
\text { (\% of GDP) }\end{array}$ \\
\hline \multirow{2}{*}{ East Asia } & \multirow{2}{*}{24} & Japan & 7 & 4.7 \\
\hline & & South Korea & 17 & -1.9 \\
\hline \multirow{2}{*}{ West Asia } & \multirow{2}{*}{15} & Armenia & 9 & 2.1 \\
\hline & & Turkey & 6 & 1.4 \\
\hline \multirow{2}{*}{ South Asia } & \multirow{2}{*}{26} & Bangladesh & 9 & 0.9 \\
\hline & & Sri Lanka & 17 & 7.3 \\
\hline \multirow{5}{*}{ Southeast Asia } & \multirow{5}{*}{66} & Indonesia & 15 & 0.6 \\
\hline & & Malaysia & 16 & $3 \cdot 3$ \\
\hline & & Philippines & 10 & 2.8 \\
\hline & & Singapore & 17 & -9.4 \\
\hline & & Thailand & 8 & -0.3 \\
\hline \multirow{2}{*}{ Oceania } & \multirow{2}{*}{24} & Australia & 13 & -0.1 \\
\hline & & New Zealand & 11 & -1.4 \\
\hline \multirow{2}{*}{ North America } & \multirow{2}{*}{28} & Canada & 17 & -0.2 \\
\hline & & US & 11 & 4.7 \\
\hline \multirow{14}{*}{ Latin America } & \multirow{14}{*}{165} & Argentina & 3 & 3.0 \\
\hline & & Bolivia & 6 & 2.0 \\
\hline & & Brazil & 15 & 2.3 \\
\hline & & Chile & 12 & -1.7 \\
\hline & & Colombia & 11 & 4.3 \\
\hline & & Dominican Republic & 7 & 1.8 \\
\hline & & Guatemala & 17 & 1.7 \\
\hline & & Honduras & 9 & 1.7 \\
\hline & & Mexico & 6 & 1.1 \\
\hline & & Nicaragua & 17 & 1.2 \\
\hline & & Paraguay & 17 & 0.3 \\
\hline & & Peru & 17 & 0.2 \\
\hline & & Uruguay & 17 & 2.0 \\
\hline & & Venezuela & 11 & 1.2 \\
\hline \multirow{5}{*}{ Eastern Europe } & \multirow{5}{*}{57} & Bulgaria & 17 & 0.7 \\
\hline & & Hungary & 17 & 5.2 \\
\hline & & Poland & 11 & 4.4 \\
\hline & & Russia & 6 & -2.8 \\
\hline & & Ukraine & 6 & 3.0 \\
\hline
\end{tabular}




\begin{tabular}{|c|c|c|c|c|}
\hline \multirow{7}{*}{ Western Europe } & \multirow{7}{*}{116} & Austria & 17 & 2.5 \\
\hline & & Belgium & 17 & 1.7 \\
\hline & & France & 17 & 3.6 \\
\hline & & Germany & 17 & 1.9 \\
\hline & & Netherlands & 17 & 1.7 \\
\hline & & Switzerland & 14 & -0.1 \\
\hline & & UK & 17 & $3 \cdot 3$ \\
\hline \multirow{4}{*}{ Northern Europe } & \multirow{4}{*}{63} & Denmark & 17 & -0.7 \\
\hline & & Finland & 17 & -1.6 \\
\hline & & Norway & 12 & -14.1 \\
\hline & & Sweden & 17 & -0.2 \\
\hline \multirow{4}{*}{ Southern Europe } & \multirow{4}{*}{68} & Greece & 17 & 7.0 \\
\hline & & Italy & 17 & 3.2 \\
\hline & & Portugal & 17 & 4.2 \\
\hline & & Spain & 17 & 1.9 \\
\hline Total & 652 & & 652 & 1.2 \\
\hline
\end{tabular}

